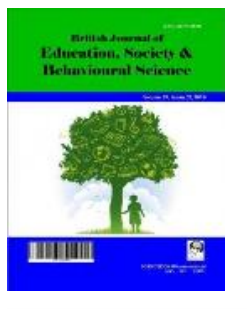

\author{
British Journal of Education, Society \& \\ Behavioural Science \\ 15(4): 1-10, 2016, Article no.BJESBS.25388 \\ ISSN: 2278-0998 \\ SCIENCEDOMAIN international \\ www.sciencedomain.org
}

\title{
Changes in Antisocial Behaviour in the Classroom and the Impact on Students, in Spain
}

\author{
Gladys Merma Molina $^{{ }^{*}}$, Salvador Peiró i Gregòri ${ }^{1}$ and Diego Gavilán Martín ${ }^{1}$
}

${ }^{1}$ Faculty of Education, University of Alicante, Carretera de San Vicente del Raspeig, s/n, C.P. 03540, Alicante, Spain.

Authors' contributions

This work was carried out in collaboration between all authors. Author GMM designed the study, wrote the protocol and supervised the work. Authors SPG and DGM carried out all laboratories work and performed the statistical analysis. Author DGM managed the analyses of the study. Author GMM wrote the first draft of the manuscript. Author SPG managed the literature searches and edited the manuscript. All authors read and approved the final manuscript.

Article Information

DOI: $10.9734 / B J E S B S / 2016 / 25388$

Editor(s):

(1) Shao-I Chiu, Taipei College of Maritime Technology of Center for General Education, Taiwan.

Reviewers:

(1) R. Praveen Sam, JNT University, Anantapur, India. (2) Kalpana L. Chaudhari, Rashtrasant Tukadoji Maharaj Nagpur University, Nagpur, India. (3) Sehrish Khan, Comsats Institute of Information and Technology, Pakistan. Complete Peer review History: http://sciencedomain.org/review-history/14279

Original Research Article

Received $29^{\text {th }}$ February 2016

Accepted $13^{\text {th }}$ April 2016

Published 21 ${ }^{\text {st }}$ April 2016

\begin{abstract}
The aim of this study is to know teachers' opinions on antisocial behaviour in the classroom and its effect on pupils. Our sample was made up of 493 secondary and primary school teachers in the Valencia Community (Spain), and the research instrument was a questionnaire elaborated by the Values, Violence and Education Interdisciplinary Research Group of the University of Alicante. The data was put on the group's online platform, and analysed using the programme SPSS v.21. The different types of antisocial behaviour highlighted by teachers were social exclusion, physical aggression and addictions, and also, but with less frequency, vandalism, insults and xenophobia. Emotional problems and a bad learning environment are the main consequences of these behaviours. Our study comes to the conclusion that there is a direct relationship between different types of school violence and pupils' negative behaviour. Thus, programmes of prevention must be developed with the aim of reducing risk factors, solving conflicts and educating pupils in specific social skills.
\end{abstract}


Keywords: School violence; values; school coexistence; secondary education; primary education; teacher.

\section{INTRODUCTION}

Violence has become a serious public health problem in many countries. For example, in the USA, adolescents and young adults are more likely to commit crimes or be victims of crime than all other age groups [1]. Studies carried out in Spain $[2,3]$ have also shown an increase in violent behaviour in young people, and have identified certain variables which affect coexistence in schools, particularly in secondary education. In short, this problem has become one of the main challenges of education systems all over the world, and of course here in Spain [4].

Most research carried out in recent years in Spain $[5,6]$ has investigated bullying and violence in schools among peers, and includes a range of different types of behaviour such as taunts, threats, intimidation, physical aggression and exclusion. These are systematic and an abuse of power of one or more pupils over a defenceless victim, while others are passive observers and do not intervene to prevent the situation [7].

A study carried out by the Ombudsman [8], with a representative sample of secondary school students and teachers from the 17 autonomous communities of Spain, stated that $31.6 \%$ of pupils claimed other pupils criticise them (indirect verbal abuse), $27.1 \%$ of pupils claim they are victims of verbal insults (direct verbal abuse), $26.7 \%$ say they are called names, $16 \%$ affirm that other pupils hide their personal possessions, $0.5 \%$ say they are ignored (indirect social exclusion), $8.6 \%$ that they are excluded (direct social exclusion), $6.4 \%$ claim that other pupils "use threats to frighten" them, $6.3 \%$ say their personal possessions are stolen, I 3.9\% affirm being hit (direct physical abuse), 3.5\% that other pupils damage their personal property (indirect physical abuse), $0.9 \%$ affirm they suffer sexual harassment, $0.6 \%$ say they are forced to do things under threat and $0.5 \%$ claim to have been threatened with weapons. In short, according to this data, the most frequent form of abuse is verbal insults, followed by social exclusion and aggression related to personal belongings (hiding or snatching). Less frequent are incidences of theft, threats, and finally, with the lowest frequency, direct physical aggression (hitting) and damage of equipment. A very small percentage of school pupils - less than $1 \%-$ state they have been victims of bribery, sexual harassment or threatened with a weapon. Contrary to the information in the latest Ombudsman Report [8], which maintains that abuse between peers has dropped in recent years, primary and secondary school teachers perceive a notable increase in behaviour which generates a series of personal, psychological, learning and social problems in pupils. In addition, some researchers like Rodríguez et al. [9] point out that intimidation in schools has a direct impact on victims and can lead to low self esteem, depression, anxiety, hatred of school etc. They also claim that those who behave aggressively can be affected in the same way.

Similarly, Martín, Pulido and Vera [10] analyse examples of school violence at different educational levels. Based on a sample of 1635 pupils aged between 14 and 18, they conclude that the most frequent types of antisocial behaviour are associated with passive social exclusion ("they give me the cold shoulder"), followed by verbal abuse ("they insult me", "they criticise me", "they call me names and make fun of me") and antisocial behaviour related to personal property ("they hide my things"). In addition, a considerable number of pupils state that they suffer more serious aggression such as verbal insults of a sexual nature, physical aggression, and threats, even with weapons. The above mentioned authors have observed that victims consider themselves to be at fault, while the perpetrators try to justify and legitimise their aggressive actions.

Another latent problem affecting adolescents, and consequently schools, is underage drinking in Spain, which has become one of the main public health and social challenges in today's society. This health problem is probably the result of identity and psychosocial development in adolescents today [11]. Young people tend to start experimenting at a younger age and this is combined with a more permissive socio cultural environment in which social contact is prioritised. A form of group interaction, associated with certain rituals, has become widespread amongst adolescents, especially at weekends [12].

As there has been little specific research into the consequences of school violence and its gravity, and considering that such behaviour affects adolescents' personal life and academic 
achievement, as proved in some studies (for example Martínez, Musitu, Amador and Monreal [13]), this research aims to investigate the presence of different forms of antisocial behaviour in primary and secondary school classrooms, and identify the effects they have on pupils.

More specifically, our study answers the following research questions: What types of antisocial behaviour exist in the classroom, according to teachers? What is the impact on pupils of the variables which influence school coexistence? This study is part of wider research which aims to analyse a broader range of antisocial behaviour variables in education centres and then elaborate specific plans of action.

\subsection{Fostering Peaceful Coexistence in Order to Eradicate School Violence}

The concept of coexistence is widely used in Social Sciences and Education and often without much precision or rigor, and so it is important to make its meaning clear.

From a global perspective, coexistence should not only be understood as a concept but as a way of life which is reflected in interpersonal and intergroup relations, and which implies that, despite conflicts and disagreements, individuals and groups involved decide to abandon violent confrontation and choose a peaceful means of reaching their objectives. This means that they are willing to establish negotiation mechanisms in order to solve conflicts, and consequently avoid a worsening in relations [14]. Coexistence begins with recognising the existence of other people and other groups with their own characteristics, values, ideology, religion, race, nationality, ethnic origin and culture, and accepting that all have the right to exist and live together peacefully, respecting the legitimate differences between them. This means that coexistence is associated on the one hand with the individuality of members of a group, that is their capacity to understand that each individual has legitimate needs, aspirations, way of being etc., and on the other hand, understanding the shared perspective of the members of a community. All this can be categorised as an educational process, the objective of which is to achieve cooperation, dialogue and social integration [15]. Thus, coexistence could be seen as the first step towards, and a necessary condition, for both personal development and for interpersonal and intergroup relations. It is the basis for harmonious and peaceful relations.

From a purely educational perspective, education for coexistence is an important part of formal education, which should foster positive beliefs, attitudes and behaviour in pupils, and have repercussions on the quality of the teachinglearning process [16], on academic achievement [17], on personal development [18] and on social change. We share the opinion of Bar-Tal [15], who maintains that education for coexistence in schools has many advantages. Firstly, school is compulsory for children and adolescents, which facilitates providing adolescents with education in coexistence. In addition, children and adolescents are in the process of developing their own personality, their character has not yet been formed and so they are more open to new ideas and information. Furthermore, the educational policies of different governments can facilitate the inclusion of education for coexistence in the curriculum. The main objectives of education for coexistence are to educate children and adolescents in values, beliefs, attitudes and emotions, and encourage behaviour which favours a harmonious school environment and eradicates the different forms of violence within and outside the education centre.

One characteristic of school violence is that it varies with pupils' age. It is most frequent amongst children and adolescents of between 9 and 17 years old, and especially during the compulsory stage of secondary school (ESO) [13]. In schools, the most prevalent forms of violence are verbal violence (harm through words), physical (direct contact with the victim), bullying or harassment amongst peers [19], cyber bullying (harassment through information technologies, mainly mobiles and the Internet) $[20,21]$, and different forms of discrimination based on gender, academic achievement or social class etc., which can cause psychological harm [22]. As regards discrimination, DeWall, Twenge, Gitter and Baumeister [23], and Park and Baumeister [24] claim that this can make pupils defensive and even antisocial or hostile. These authors affirm that pupils who suffer exclusion do not know how to cooperate and can occasionally become aggressive.

However, a bad classroom environment, a lack of interest in studies and difficulties in keeping up with school work are also related to other factors such as disruption, when pupils' behaviour interferes with the normal running of classes [25], 
interruptions, lack of concentration, discipline problems, and absenteeism, both in primary and secondary schools. In fact, discipline problems are often associated with school failure in specialist literature. In the case of Spain, $28 \%$ of academic failure reflects some type of discipline problem, which means that pupils with discipline problems make up more than a quarter of pupils who fail. Pupils with a disciplinary school record are often amongst those who abandon their studies during the first cycle of ESO (Compulsory Secondary School), followed by those who abandon during the second cycle (37\%). Pupils who abandon during the post compulsory stage $(8 \%)$ are in the minority [26]. Thus, in this context, it is normal to see absenteeism as a precursor to abandonment [27]. To summarise, the above information indicates that there is a wide range of factors which affect coexistence in the classroom and which can cause psychological, social, physical and academic problems such as social exclusion, depression, and low self-esteem. They are also predictors of future aggressive behaviour, and can even lead to the consumption of drugs, absenteeism and academic failure $[28,29]$. In order to deal with these problems, schools must consider applying two different types of strategies, those for prevention and those aimed at solving the problems, both in the classroom and in the educational centre as a whole. Efforts to introduce strategies of prevention have proved to be very promising for the prevention of violent behaviour [1]. The aim of these is to reduce the risk factors, to take a proactive approach to problem behaviours before they become chronic. Such strategies have proved to have a higher success rate than strategies of intervention. For example, preventative action focused on improving academic achievement through changes in classroom management, in primary education, could reduce aggressive conduct [30]. In addition, academic achievement and personal experiences of school life are related to the risk of violence [31]. It seems that children with little interest in school and who do badly in their studies from a young age are at greater risk. Furthermore, they are at risk not only in the educational centre, but also outside.

\section{METHODOLOGY}

\subsection{The Sample}

The sample was made up of $\mathrm{N}=493$ teachers (241 primary school teachers and 252 secondary school teachers) of the Valencian Community (Spain). The pupils who made up the sample were divided proportionally between the two educational stages. The participants were aged between 10 and 14 years old. As regards the type of centre, 12 primary school teachers worked in private centres, 147 in subsidized centres, and 334 in state schools.

\subsection{Research Instrument}

The research instrument used was a questionnaire called School coexistence variables and their impact on education [32], elaborated by the Values, Violence and Education Interdisciplinary Research Group of the Education Faculty, University of Alicante. It included 6 forms of school violence: addiction, physical aggression, discrimination, insults, vandalism, and xenophobia. Each type of violence had 7 possible consequences: a bad learning environment, school abandonment, emotional problems, dependency, insecurity, social exclusion, and academic failure. The research instrument was composed of 15 scaled items for which participants had to reply "Yes" (when the behaviour had such an impact) or "No" (if the behavior did not have the said impact)

The research instrument was validated by 8 lecturers, experts in the subject of Theory and History of Education at Alicante University. In order to do this, they took into account the emerging themes of previous studies $[3,32,33]$ related to the area under investigation, and finally decided on the antisocial behaviour variables and their possible consequences. The internal consistency (Cronbach's Alpha) of the questionnaire was .85 .

\subsection{Procedure}

Firstly, the sample group was selected using stratified random sampling with proportional allocation. In order to do this, state, subsidized and private education centres of the Valencia Community (Spain) were considered. Then, the head teachers of the centres chosen were contacted in order to ask for their consent to carry out the research. Once the corresponding permission was received, during the month of October, 2014, teachers of primary school Year 6 , and the 1st and 2nd year of secondary school were contacted and informed of the objectives of the study and that it would be anonymous, confidential and voluntary. In November of the 
same year, the questionnaire was given to the teachers who had volunteered to take part. The teachers answered the questionnaire in their free time in their own education centre.

Once the questionnaires had been completed, the data was transcribed and organised on the online platform of the Values, Violence and Education Interdisciplinary Research Group (http://violencia.dste.ua.es/). Each questionnaire had an alphanumeric verification code (for example, ENCAJJ14Q7HV), which facilitated the processing of the information. After this, analysis and interpretation was carried out with the programme Statistical Package for Social Science (SPSS) v.21 on the same virtual platform. Finally, the results were analysed, establishing the possible relations between antisocial behaviour factors and the impact on pupils.

\section{RESULTS}

The results show the existence of 6 types of antisocial behaviour in the classroom: addiction to alcohol, drugs and video games, physical aggression, discrimination, insults, vandalism and xenophobia (Fig. 1).

Discrimination is the most common (51.39\%), followed by physical aggression (50.60\%) and addiction $(48.94 \%)$. The relation between the different antisocial behaviour and the impact on pupils can be seen in Table 1 .

According to the teachers taking part in the study, discrimination is the most common variable and mainly causes emotional problems $(64.50 \%)$, social exclusion $(62.50 \%)$ and feelings of insecurity (61.70\%). Physical aggression creates a bad learning environment (65.20\%), emotional problems (64.30\%) and insecurity in pupils (62.20\%). Addiction to alcohol, cigarettes and videogames lead to academic failure $(67.20 \%)$, school abandonment $(63.10 \%)$ and emotional problems (53.80\%).

Fig. 2 shows the impact on pupils of the most common forms of antisocial behaviour in the classroom and education centres.

The fourth most common type of antisocial behaviour given by teachers is vandalism, which creates a bad learning environment (64.60\%), leads to academic failure $(57.50 \%)$ and school abandonment $(49.70 \%)$. This is followed by insults, which also create a bad learning environment $(69.70 \%)$, emotional problems $(65.50 \%)$ and insecurity in pupils (54.40\%). Finally, the sixth factor highlighted by teachers was xenophobia, which causes emotional problems $(58.50 \%)$, social exclusion $(55.60 \%)$ and a bad learning environment (53.70\%) (Fig. 3).

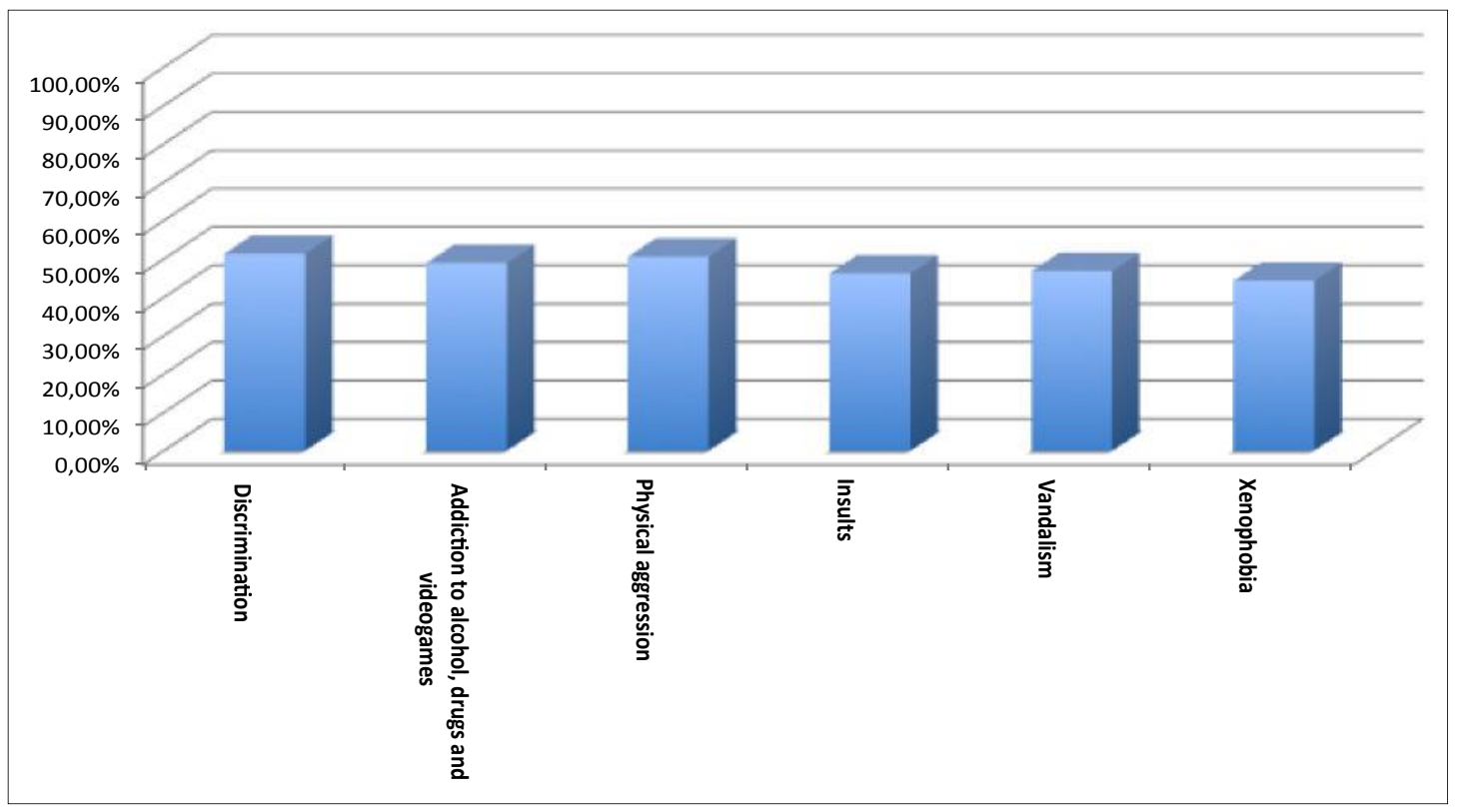

Fig. 1. Types of antisocial behaviour 


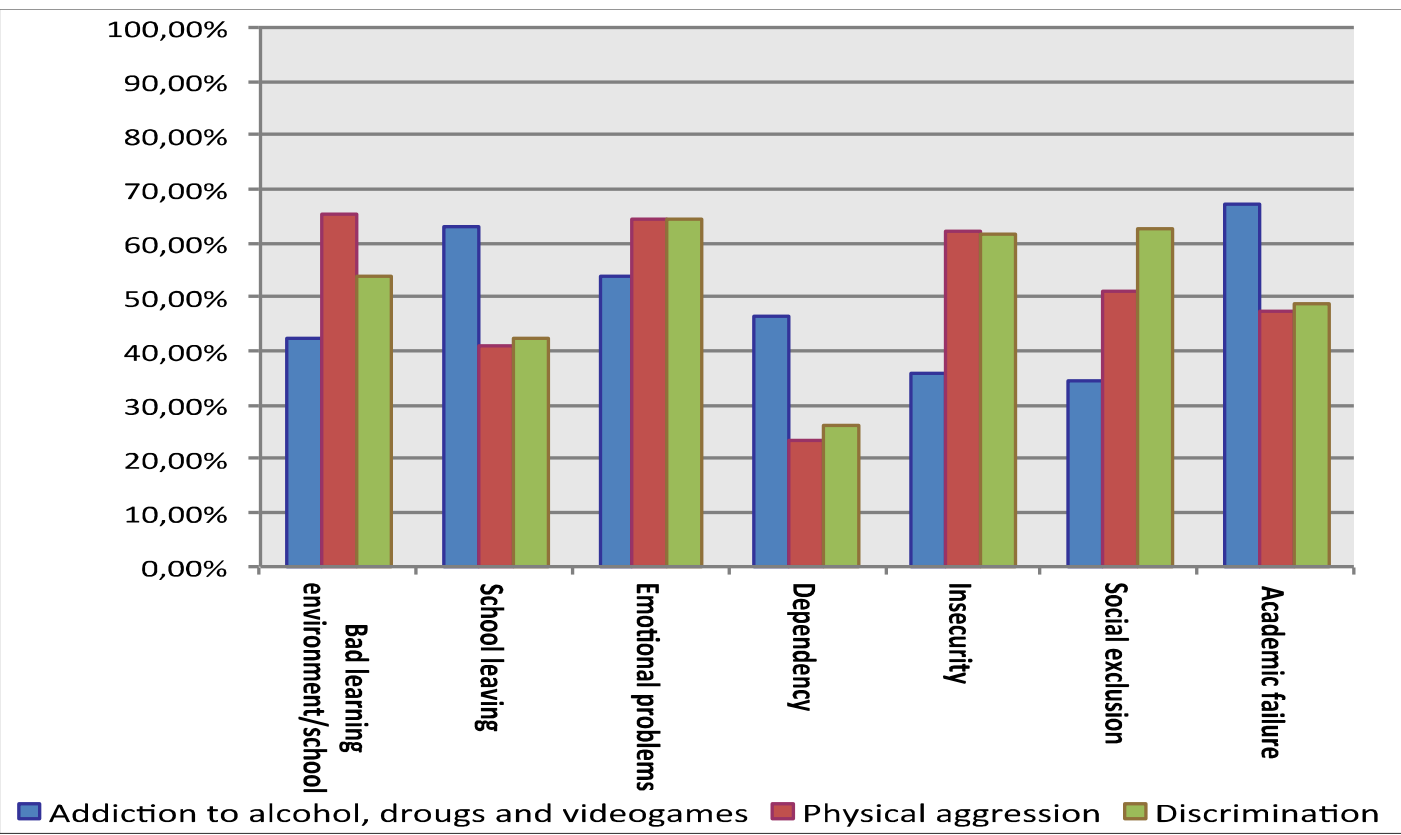

Fig. 2. Consequences of the most common forms of antisocial behaviour

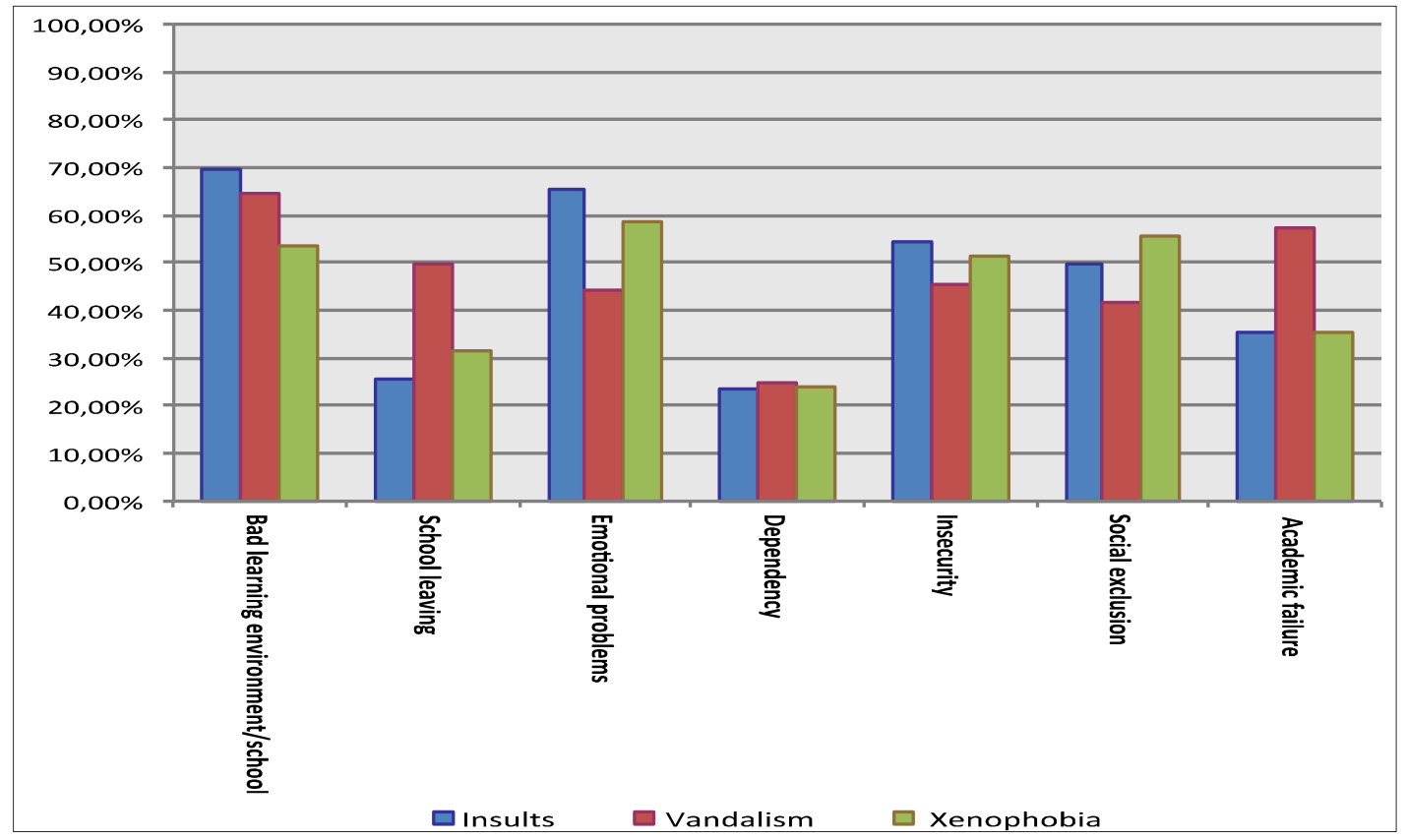

Fig. 3. Consequences of the less frequent forms of antisocial behaviour

\section{DISCUSSION AND CONCLUSIONS}

Several studies (for example, Lösel and Farrington [34] and Menard, Weiss, Franzese, Covey [35]) have shown that behavioural problems appear at a very early age and become more serious in adolescence, and that schools are potentially able to reduce the appearance of these forms of conduct [36]. This research, motivated by these facts, analysed the different forms of antisocial behaviour in the classroom and the possible impact on pupils. 
Table 1. Antisocial behaviour and its consequences

\begin{tabular}{lllllll}
\hline & $\begin{array}{l}\text { Addiction to } \\
\text { alcohol, } \\
\text { drugs and } \\
\text { videogames }\end{array}$ & $\begin{array}{l}\text { Physical } \\
\text { aggression }\end{array}$ & Discrimination & Insults & Vandalism Xenophobia \\
& $42.20 \%$ & $65.20 \%$ & $53.70 \%$ & $69.70 \%$ & $64.60 \%$ & $53.70 \%$ \\
\hline $\begin{array}{l}\text { Bad learning } \\
\text { environment }\end{array}$ & & & & & & \\
Abandonment of \\
studies
\end{tabular}

The results and analysis of the data have led to some general and specific conclusions. Firstly, the results demonstrate that different types of school violence occur in the classroom, the most frequent being discrimination, physical aggression and addiction. Less frequent, but also common, are vandalism, insults and xenophobia. The consequences of such behaviour are mainly emotional problems and a bad learning environment. These results differ partially from some other studies which maintain that the most common factors influencing the classroom environment, in Spain, are disruption [37] and verbal violence $[38,8,39]$ and that the least common forms of antisocial behaviour are sexual harassment and threats with weapons [40]. The results do agree in part with research by Martín, Pulido and Vera [10], who highlight passive exclusion as the most frequent form of school violence.

It can be concluded, after a more specific analysis of the relation between the different types of antisocial behaviour evident in our study, that from the teachers' point of view, discrimination, physical violence verbal violence and racism cause emotional problems in pupils. These results complement the findings of Estévez et al. [41] and Rodríguez, Mirón \& Rial [42], who stress that ostracised pupils have low self esteem, emotional problems, and greater learning problems and are less motivated than adolescents who are socially accepted. This has a negative effect on their personal, social and academic life [43]. Similarly, this research indicated that physical violence, verbal violence, vandalism and xenophobia create a bad learning environment. Addiction and vandalism lead to academic failure, and discrimination and racism to social exclusion. These results are concordant with other studies carried out in Spain, which have referred to, described and analysed different types of aggression, amongst which physical and verbal violence, damage to property, theft, and other forms of aggression stand out $[8,10]$. These all have an impact on a person's social and emotional development.

Problems such as addiction to alcohol, videogames and tobacco require special mention. We are living in an age when alcohol consumption has become a customary part of adolescents' leisure time, and plays an important role in group identification. In Spain, consumption and abuse of alcohol have reached massive proportions, becoming a ritual in large open spaces and referred to as a "botellón" (open air drinking party) [44]. Teachers highlight the consequences of addiction as being emotional problems, academic failure and abandonment of studies. The findings of this research show that drug and alcohol consumption, and addiction to videogames, are becoming problems at an increasingly younger age. The participants in the sample were between 10 and 14 years old and alcohol was the legal drug most consumed, which corroborates the conclusions of other studies carried out both in Latin America [45] and Spain $[11,46]$.

Little research has been carried out into xenophobia, which, according to the research, generates emotional problems, social exclusion and a bad learning environment. Also, few studies have investigated sufficiently the effects of this problem on pupils. The results coincide partially with research carried out by Rodríguez, Ortega, Zych [47], who have shown that discrimination based on ethnicity and culture can generate social-affective difficulties, and that these pupils suffer multiple forms of racial victimisation as it is difficult for them to find 
classmates who share their identity. In today's society, where racial conflicts are ever more serious, the relationship between victimisation and race suggests that this type of discrimination in adolescents should be included in education programmes for coexistence, fostering education in respect for other people's beliefs and attitudes, and for shared social norms [48].

Thus it can be seen that due to the many factors which influence coexistence, achieving a positive school environment is a big challenge but not impossible. Knowing these variables and their impact is the first important step to designing prevention strategies with an empirical base. Determining the different mechanisms by which the risk factors examined influence the behaviour of young people, will take us a step nearer to reducing violence in schools by means of efficient and proactive prevention measures.

Consequently, the approval of educational policy which encourages coexistence is not enough. It is vital that specific active measures are developed and put into practice. School curriculums should include these subjects, text books contain personal and social values, and teachers must be trained in this area. In addition, experimental programmes should be developed and positive learning programmes created.

Given the limited access students and university teachers have to schools, in Spain, an experimental programme with student primary school teachers is being carried out in the Education Faculty of the University of Alicante (Spain). The transversal topic of Coexistence has been incorporated in the subject Theory and History of Education, and includes specific contents on values, coexistence and antisocial behaviour in schools.

\section{COMPETING INTERESTS}

Authors have declared that no competing interests exist.

\section{REFERENCES}

1. Herrenkohl TI, Maguin E, Hill KG, Hawkins JD, Abbott RD, Catalano RF. Developmental risk factors for youth violence. Journal of Adolescent Health. 2000;26(3):176-186.

2. Álvarez $D$, Dobarro $A$, Núñez JC, Rodríguez C. La violencia escolar en los centros de educación secundaria de
Asturias desde la perspectiva del alumnado. Educación XX1. 2014;17(2): 337-360. Spanish.

3. Merma G, Peiró S, Gavilán D. Perspectivas sobre educación en valores en tiempos de crisis. Barataria: Revista Castellano-Manchega de Ciencias Sociales. 2013;(15):151-160. Spanish.

4. Gázquez JJ, Pérez MC, Lucas $F$, Fernández M. Análisis de la convivencia escolar por los docentes europeos. Aula Abierta. 2009;37:11-18. Spanish.

5. Cerezo F, Sánchez C, Ruiz C, Arense JJ. Adolescents and preadolescents' roles on bullying, and its relation with social climate and parenting styles//roles en bullying de adolescentes y preadolescentes, y su relación con el clima social y los estilos educativos parentales. Journal of Psychodidactics. 2014;20(1):139-155. Spanish.

6. Díaz-Aguado MJ, Martínez R, Babarro, JM. El acoso entre adolescentes en España. Prevalencia, papeles adoptados por todo el grupo y características a las que atribuyen la victimización. Revista de Educación. 2013;362:348-379. Spanish.

7. Díaz-Aguado MJ. La violencia entre iguales en la adolescencia y su prevención desde la escuela. Psicothema. 2005;17(4):549-558. Spanish.

8. Defensor del Pueblo-UNICEF. Violencia escolar: el maltrato entre iguales en la Educación Secundaria Obligatoria 19992006. Madrid: Publicaciones de la Oficina del Defensor del Pueblo; 2007. Spanish.

9. Rodríguez JM, Martínez R, Díaz-Aguado MJ, Morentín R. Comportamiento violento en adolescentes: su relación con las estrategias cognitivas y el rendimiento académico. Psicología Educativa. 2008; 14(1):63-81. Spanish.

10. Martín G, Pulido R, Vera R. Maltrato entre iguales y exclusión social en la Comunidad de Madrid. Análisis y posibilidades de intervención. Psicología Educativa. 2008;14(2):103-113. Spanish.

11. De la Villa $M$, Ovejero A. Consumo abusivo de alcohol en adolescentes españoles: Tendencias emergentes y percepciones de riesgo. Universitas Psychologica. 2011;10(1):71-87. Spanish.

12. Cortés MT, Espejo B, Giménez JA. Aspectos cognitivos relacionados con la práctica del botellón. Psicothema. 2008;20(3):396-402. Spanish. 
13. Martínez B, Musitu G, Amador LV, Monreal MC. Estatus sociométrico y violencia escolar en adolescentes: implicaciones de la autoestima, la familia y la escuela. Revista Latinoamericana de Psicología. 2012;44(2):55-66. Spanish.

14. Prenzel PV, Vanclay F. How social impact assessment can contribute to conflict management. Environmental Impact Assessment Review. 2014;45:30-37.

15. Bar-Tal D. Nature, rationale, and effectiveness of education for coexistence. Journal of Social Issues. 2004;60(2):253271.

16. Dobarro A, García T, Álvarez D. ¿Qué medidas para la mejora de la convivencia se están desarrollando en los centros educativos?: una perspectiva desde dentro. European Journal of Investigation in Health, Psychology and Education. 2013;3(3):207-213. Spanish.

17. Moral JC, Sánchez JC, Villarreal ME. Desarrollo de una Escala Multidimensional Breve de Ajuste Escolar. Revista Electrónica de Metodología Aplicada. 2010;15(1):1-11. Spanish.

18. Cerezo F. Acoso escolar. Efectos del bullying. Boletín de la Sociedad de Pediatría de Asturias, Cantabria, Castilla y León. 2008;48:353-358. Spanish.

19. Olweus D. Bullying at school. Oxford: Blackwell. Trad. cast. de A. Gallardo: Conductas de acoso y amenaza entre escolares. Madrid: Morata; 1993. Spanish.

20. Félix V, Soriano M, Godoy G, Sancho S. El ciberacoso en la enseñanza obligatoria. Aula Abierta. 2010;38(1):47-58. Spanish.

21. Ortega R, Núñez JC. Bullying and cyber bullying: Research and intervention at school and social contexts. Psicothema. 2012;24(4):603-607.

22. Rodríguez RM. Éxito académico de los estudiantes inmigrantes. Factores de riesgo y de protección. Educación XX1. 2010;13(1):101-123. Spanish.

23. DeWall CN, Twenge JM, Gitter SA, Baumeister RF. It's the thought that counts: The role of hostile cognition in shaping aggressive responses to social exclusion. Journal of Personality and Social Psychology. 2009;96:45-59.

24. Park J, Baumeister RF. Social exclusion causes a shift toward prevention motivation. Journal of Experimental Social Psychology. 2015;56:153-159.

25. Hulac DH, Benson N. The use of group contingencies for preventing and mana- ging disruptive behaviors. Intervention in School \& Clinic. 2010;45(4):257-262.

26. Fernández M, Mena L, Riviere J. Fracaso y abandono escolar en España. Colección Estudios Sociales, 29. Obra Social Fundación La Caixa; 2010. Spanish.

27. Rúe J. El absentismo escolar. Cuadernos de pedagogía. 2003;(327):50-54. Spanish.

28. Corbí B, Pérez MA. The effect of absenteeism and school failure in the consumption of snuff in a sample of students in 3rd and 4th of Secondary Education/El efecto del absentismoy el fracaso escolar en el consumo de tabaco, en una muestra de estudiantes de $3^{\circ}$ y $4^{\circ}$ de Educación Secundaria. Health and Addictions/Salud y Drogas. 2013;13(1):16. Spanish.

29. Díaz-Aguado MJ, Martínez R, Ordóñez A. Prevenir la drogodependencia en adolescentes y mejorar la convivencia desde una perspectiva escolar ecológica. Revista de Educación. 2013;(1):338-362. Spanish.

30. Leflot $G$, van Lier PA, Onghena P, Colpin, $\mathrm{H}$. The role of children's on-task behavior in the prevention of aggressive behavior development and peer rejection: $A$ randomized controlled study of the good behavior game in Belgian elementary classrooms. Journal of School Psychology. 2013;51(2):187-199.

31. Henry KL, Knight KE, Thornberry TP. School disengagement as a predictor of dropout, delinquency, and problem substance use during adolescence and early adulthood. Journal of Youth and Adolescence. 2012;41(2):156-166.

32. Ochoa A, Peiró S. Estudio comparativo de las actuaciones de los profesores ante situaciones que alteran la convivencia escolar. El caso de Querétaro (México) y Alicante (España). Revista Electrónica Interuniversitaria de Formación del Profesorado. 2010;13(4):113-122. Spanish

33. Ochoa A, Peiró S. El quehacer docente y la educación en valores. Education in the Knowledge Society. 2012;13(3):28-48. Spanish.

34. Lösel F, Farrington DP. Direct protective and buffering protective factors in the development of youth violence. American Journal of Preventive Medicine. 2012; 43(2):S8-S23.

35. Menard S, Weiss AJ, Franzese RJ, Covey HC. Types of adolescent exposure to violence as predictors of adult intimate 
partner violence. Child Abuse \& Neglect. 2014;38(4):627-639.

36. Brewer DD, Hawkins JD, Catalano RF, Neckerman HJ. Preventing serious, violent, and chronic juvenile offending. In: Howell JC, Krisberg B, Hawkins JD, Wilson JJ, editors. A sourcebook: Serious, violent and chronic juvenile offenders. Thousand Oaks, CA: Sage. 1995;61-141.

37. Álvarez D, Núñez JC, Dobarro A. CUVE3. Cuestionario de Violencia Escolar-3. Barakaldo: ALBOR-COHS; 2012. Spanish.

38. Díaz-Aguado MJ, Martínez R, Martín J. Estudio Estatal sobre la convivencia escolar en laEducación Secundaria Obligatoria. Madrid: Ministerio de Educación, Observatorio Estatal de la Convivencia; 2010. Spanish.

39. Núñez JC, Álvarez $\mathrm{D}$, Rodríguez $\mathrm{C}$, González P, Álvarez L, González JA. Diferencias de género en el nivel de violencia escolar percibido por los estudiantes de Educación Secundaria. En: Gázquez JJ, Pérez MC, editores. Investigación en convivencia escolar. Variables relacionadas. Granada: Grupo Editorial Universitario. 2010;181-182. Spanish.

40. Álvarez D, Núñez JC, Álvarez L, Dobarro A, Rodríguez C, González P. Violencia a través de las tecnologías de la información y la comunicación en estudiantes de secundaria. Anales de Psicología. 2011;27(1):221-231. Spanish.

41. Estévez E, Herrero J, Martínez B, Musitu G. Aggresive and non-aggresive rejected students. An analysis of their differences. Psychology in the Schools. 2006:43(3): 387-400.
42. Rodríguez J, Mirón L, Rial A. Análisis de la relación entre grupo de iguales, vinculación familiar y escolar, autocontrol y conducta antisocial, en una muestra de adolescentes venezolanos. Revista de Psicología Social. 2012;27:25-38. Spanish.

43. Cava MJ, Buelga S, Musitu G, Murgui S. Violencia escolar entre adolescentes y sus implicaciones en el ajuste psicosocial: un estudio longitudinal. Revista de Psicodidáctica. 2010;15(1):21-34. Spanish.

44. Gómez JA, Pérez NF, Trínanes ER. El botellón y el consumo de alcohol y otras drogas en la juventud. Psicothema. 2008;20(2):211-217. Spanish.

45. Torres MC, Palma MM, Iannini J, Moreno S. Validación de la prueba young adult alcohol problems screening test, YAAPST en un grupo de estudiantes universitarios de la Pontificia Universidad Javeriana de Bogotá. Universitas Psychologica. 2006; 5(1):175-190. Spanish.

46. Moniño M, Piñero E, Arense J, Cerezo F. Violencia escolar y consumo de alcohol y tabaco en estudiantes de Educación Secundaria. EJIHPE: European Journal of Investigation in Health, Psychology and Education. 2013;(2):137-147. Spanish.

47. Rodríguez AJ, Ortega R, Zych I. Peer victimization and ethnic-cultural peer victimization: self-esteem and school relations between different cultural groups of students in Andalusia, Spain. Journal of Psychodidactics. 2013;19(1):191-210.

48. Levin J. The violence of hate: Confronting racism, anti-Semitism, and other forms of bigotry. Boston: Allyn and Bacon; 2002.

(c) 2016 Molina et al.; This is an Open Access article distributed under the terms of the Creative Commons Attribution License (http://creativecommons.org/licenses/by/4.0), which permits unrestricted use, distribution, and reproduction in any medium, provided the original work is properly cited.

Peer-review history:

The peer review history for this paper can be accessed here: http://sciencedomain.org/review-history/14279 